\title{
Comparison of Personal Pronoun between Arabic and Its Indonesian Translation of Koran
}

\author{
Markhamah (Corresponding author) \\ Pendidikan Bahasa Indonesia (PBI) (Indonesion Language Education), FKIP (School of Teacher Training and Education) \& \\ Magister Pengkajian Bahasa (MPB) (Language Studies), Sekolah Pascasarjana, Universitas Muhammadiyah Surakarta, A. Yani, Tromol Pos 1, \\ Surakarta, 57102, Indonesia \\ E-mail: markhamah@ums.ac.id \\ Abdul Ngalim \\ School of Teacher Training and Education, Universitas Muhammadiyah Surakarta, A. Yani, Tromol Pos 1, Surakarta, 57102, Indonesia \\ E-mail: ngalim_46@yahoo.com \\ Muhammad Muinudinillah Basri \\ School of Islam, Universitas Muhammadiyah Surakarta, A. Yani, Tromol Pos 1, Surakarta, 57102, Indonesia \\ E-mail: basri_salam@yahoo.com \\ Atiqa Sabardila \\ School of Teacher Training and Education, Universitas Muhammadiyah Surakarta A. Yani, Tromol Pos 1, Surakarta, 57102, Indonesia \\ E-mail: as193@ums.ac.id
}

Received: 04-03-2017

Published: 01-09-2017
Accepted: 19-05-2017

doi:10.7575/aiac.ijalel.v.6n.5p.238
Advance Access Published: July 2017

URL: http://dx.doi.org/10.7575/aiac.ijalel.v.6n.5p.238

\begin{abstract}
The system of pronoun in Indonesian language and Arabic is diverse. This becomes the main consideration of the emergence of the current study. This comparative-descriptive-qualitative study aims at comparing the Indonesian translation of Quran with its Arabic version to differentiate pronouns of both languages in relation to gender (male, female, neutral), grammatical categories of number (singular, plural, dual), and tenses (past, present, and future). AlQur'an which is written in Arabic is then compared to the Indonesian translation of it. Moreover, the objects of the research are personal pronouns and the data are all linguistic units consisting of personal pronouns in the Indonesian translation of Quran compared to its Arabic version. The data were collected through content analysis. Then, the comparative and distributional methods were employed to analyze the data. The findings show that in terms of gender, personal pronoun has different translation in the two languages. Indonesian does not distinguish the personal pronoun that refers to male or female, while Arabic does. In terms of quantity, Indonesian first person pronoun kami 'we' is commonly used for plural. However in the translated verses, kami 'we' refers to both singular and plural. Furthermore, in terms of tenses, Indonesian and Arabic utilize different systems. Indonesian does not distinguish the pronoun in terms of past, present, or future act, while Arabic adjusts the grammatical conformity between the verb and the subject or between the adverb and the subject in relation to number, person, and gender to express an element of tense.
\end{abstract}

Keywords: gender, grammatical category of number, personal pronoun, tense

\section{Introduction}

The difference of the system of pronoun in Indonesian and Arabic language becomes this present research's deliberation. It is not only happened to the opus of Indonesian and Arabic language, however, in any cases of language around the world (e.g. English to Indonesian language). Language in every single country has its own system. In this case, the system may transpire the divergence. Directly regarding to this current study, the intended languages which are presented in this paper are English and Arabic; that the personal pronoun, numbers, and gender signify the verb forms. The followings are the examples which are able to clarify the explanation.

(a) Saya membaca buku. 'I read a book.'

(b) Kamu sekalian membaca buku.

'You all read a book.'

(c) Bambang membaca buku.

'Bambang (name of person for male) reads a book.' 
(d) Wartini membaca buku.

'Wartini (name of person for female) reads a book.'

Sentences (a) and (b) employ the different forms of subject related to the number, while the pronouns in sentence (c) and (d) utilize the different forms of subject pronoun due to the gender. However, the verb form in all sentences is actually the same: membaca 'to read'. Meanwhile, Arabic has a different system, as shown in sentences (e) and (f) as follows.

(e) Al-bintu takallamat dahikatan.

S V Adv.

Itu-anak perempuan bercakap-cakap-dia yang tertawa

'it-girl-talk-she-laughs'

(f) Al-bintani takallamataa dahikataini.

S V Adv.

Itu-dua anak perempuan bercakap-cakap-dia berdua yang mereka berdua tertawa

'it-two girls-talk-she-laughs-they laugh'

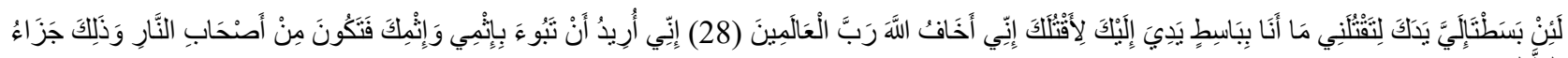

Sungguh kalau kamu menggerakkan tanganmu kepadaku untuk membunuhku, aku sekali-kali tidak akan menggerakkan tanganku kepadamu untuk membunuhmu, sesungguhnya aku takut kepada Allah Tuhan seru sekalian alam.

The verb basatta of engkau menggerakkan atau membentangkan is used for the second person with the second person singular personal pronoun, the object is adjusted into yadaka or tanganmu 'your hand'. Therefore, the word ana 'I' is adjusted to the word isim fail bibasit or saya menggerakkan 'I move' and yadii or tanganku 'my hand'.

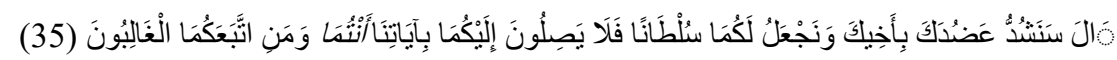

Allah berfirman: Kami akan membantumu dengan saudaramu, dan kami berikan kepadamu berdua kekuasaan yang besar, maka mereka tidak dapat mencapaimu, berangkatlah kamu berdua dengan membaba mukjizat Kami, kamu berdua dan orang yang mengikuti kamulah yang menang.

The above translation is from Department of Religious Affairs of Indonesia with several changes. The following is considered more literal and proper translation

Dia (Allah) berfirman: Kami akan kuatkan lenganmu dengan saudaramu dan Kami menjadikan buat kalian berdua kekuatan, maka dia (Fir'aun) tidak dapat sampai kepada kalian berdua. Dengan ayat-ayat Kami, kalian berdua dan orang yang mengikuti kalian berdua adalah orang-orang yang menang.

The word adzudaka or lenganmu 'your hand' is adjusted to be bi akhika or saudaramu 'your brother', naj'alu lakuma or kami menjadikan kalian berdua 'We make both of you'.

The above is the translation version of Department of Religious Affairs of Indonesia with several changes. Then, the following is the more literal translation, which is adjusted to its original text in Arabic.

"Kemudian kalian (wahai bani isroil) membunuh diri kalian (saudara kalian sebangsa) dan kalian mengusir segolongan dari kalian dari kampung halaman mereka, kalian saling konsiparasi atas mereka dengan membuat dosa dan permusuhan, tetapi jika mereka datang kepada kalian sebagai tawanan kalian tebus mereka, dan itu (mengusir mereka) juga terlarang bagimu."

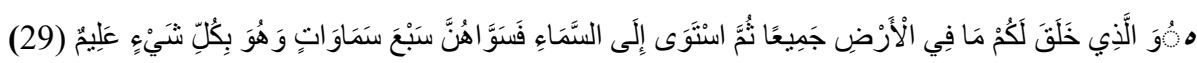

Dialah Allah yang menjadikan segala yang ada di bumi untuk kamu dan Dia berkehendak menuju ke langit lalu dijadikan tuju langit dan Dia Maha mengetahui segala sesuatu.

The above translation is from the Department of Religious Affairs of Indonesia, where the second plural pronoun should be kalian 'you (in plural)' or kamu sekalian 'you (in plural)' instead of kamu 'you'.

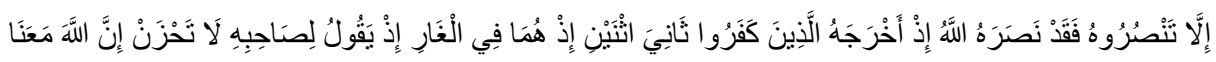

“Jika kamu tidak menolongnya (Muhammad) maka sesungguhnya Allah telah menolongnya yaitu ketika orang-orang dari Mekah mengeluarkannya dari Mekah sedang dia salah seorang dari dua orang ketika kedua-duanya berada dalam gua, diwaktu itu dia berkata kepada temannya janganlah kamu berduka cita, sesungguhnya Allah beserta kita”

The pronoun jika kamu 'if you', should be kamu sekalian 'you (in plural).

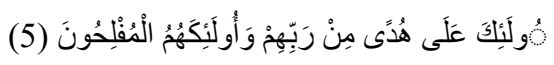

Mereka itulah yang tetap mendapat petunjuk dari Tuhan mereka, dan merekalah orang-orang yang beruntung.

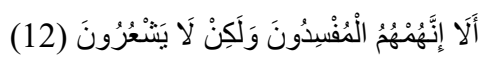

Ingatlah mereka itulah orang yang membuat kerusakan tetapi mereka tidak sadar.

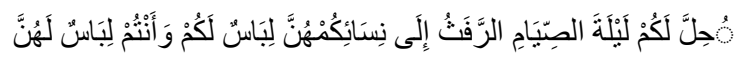


Dihalalkan bagi kamu pada malam hari bukan puasa bercampur dengan istri-istri kamu, mereka itu adalah pakaian bagimu dan kamupun pakaian dari mereka.

In the translation above, the personal pronoun lakum should be translated into kalian semиa 'you (in plural)' instead of кати 'you (in singular).

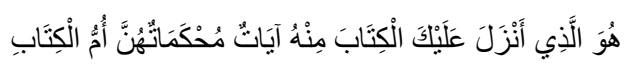

Dialah yang menurunkan Al-Qur'an kepada kamu, diantara isinya ada ayat-ayat yang muhkamat itulah pokok-pokok isi Al-Qur'an.

Neutral pronouns are also used for plural form of hunna or ayat-ayat 'articles' and it is translated into itu 'that'. In Arabic, it also means plural form for hunna (mereka perempuan) 'they (woman)'.

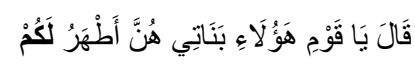

Luth berkata: hai kaumku inilah putrid-putri (negeri)ku mereka lebih suci bagimu

In this verse, the translation is adjusted into putri-putri with feminine plural pronoun hunna (mereka perempuan) 'they (woman)'.

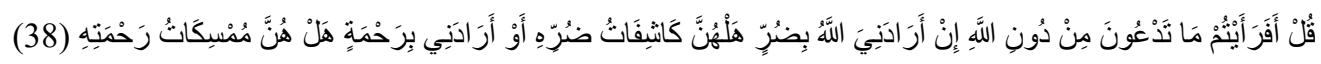

Maka terangkan kepadaku tentang apa yang kamu seru selain Allah jika Allah hendak mendatangkan keudharatan kepadaku apakah berhala-berhalamu itu dapat menghilangkan kemudharatan itu, atau jika Allah hendak member rahmat kepadaku apakah mereka dapat menahan rahmatnya.

The neutral plural pronouns are considered as feminine which are adjusted to those that are worshipped with hunna (mereka perempuan) 'they (woman)'.

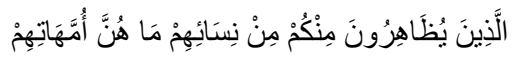

Orang-orang yang mendzihar istrinya diantara kamu, menganggap istrinya sebagai ibunya (padahal) tiadalah istri mereka itu ibu mereka.

It uses pronoun hunna for the word nisaiihinna (istri-istri mereka) 'their wife'.

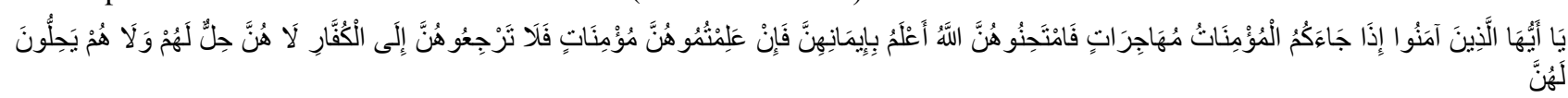

Hai orang orang beriman apabila datang berhijrah kepadamu perempuan perempuan yang beriman maka hendaklah kaти uji keimanan mereka Allah lebih mengetahui keimanan mereka maka jika kamu mengetahui bahwa mereka benar benar beriman maka janganlah kamu kembalikan mereka kepada suami suami mereka orang orang kafir, itu dan orang orang kafir itu tidak halal bagi orang orang kafir itu dan orang orang kafir tidak halal bagi mereka.

The use of feminine plural pronoun is adjusted to the feminine plural word for mukminaat with hunna.

Al-Qur'an also employs the first-person, second-person and more dual pronouns for nahnu or naa, which means kami 'we'.

For example:

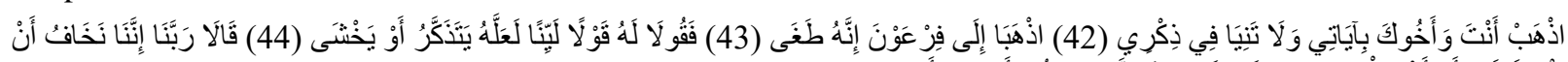

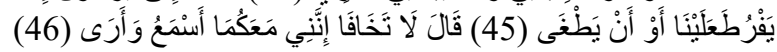

Pergilah kaтu beserta saudaramu dengan membawa ayat- ayat-Ku dan janganlah kamu berdua lalai dalam mengingatKu(42). Pergilah kamu berdua kepada fir'aun sesungguhnya dia telah melampaui batas (43). Maka berbicaralah kamu berdua kepadanya dengan kata kata yang lemah lembut, mudah mudahan ia ingat atau takut (44). Berkatalah mereka berdua: "ya tuhan kami sesungguhnya kami kawatir bahwa ia segera menyiksa kami atau akan bertambah melampui batas".

The phrase kami khawatir uses plural pronoun for dual.

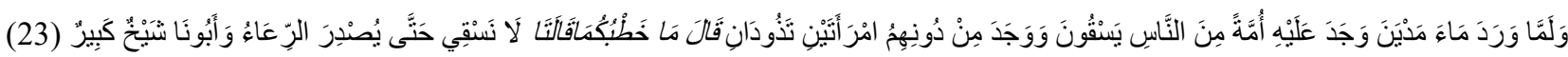

Dan tatkala ia sampai di sumber air negeri Madyan ia menjumpai di sana sekumpulan orang yang sedang meminumkan ternaknya dan dibelakang orang banyak itu dua orang wanita yang sedang menghambat ternaknya musa berkata: apakah maksudmu dengan berbuat begitu kedua wanita itu menjawab kami tidak dapat meminumkan ternak kami sebelum pengembala-pengembala itu memulangkan ternaknya, sedang bapak kami adalah orang tua yang telah lanjut umurnya.

The above is the translation from Department of Religious Affairs of Indonesia. If the pronoun translation needs to be adjusted, then it should be as follows.

Dan tatkala ia sampai di sumber air negeri madyan ia menjumpai di sana sekumpulan orang yang sedang meminumkan ternaknya dan dibelakang orang banyak itu dua orang wanita yang sedang menghambat ternaknya musa berkata: apakah maksud kalian berdua dengan berbuat begitu kedua wanita itu menjawab kami tidak dapat meminumkan ternak kami sebelum pengembal pengembala itu memulangkan ternaknya, sedang bapak kami adalah orang tua yang telah lanjut umurnya.

The second one uses first-person dual pronoun and plural pronoun, kami 'we', bapak kami 'our father'. 


\section{Literature Review}

In this section, this study elaborates the literatures regarding to the study. It is started by elucidating the pronoun in Arabic language, pronoun in Indonesian language, translation of Arabic pronoun, studies on personal pronoun in Arabic, and the recent study about the language in Al-Qur'an. The following is the brief elaboration.

\subsection{Pronouns in Arabic Language}

Dhamir in Arabic means pronoun in Bahasa Indonesia. Dhamir is isim function to replace the mention of something/someone or a group of thing/people (Pamungkas, 2013; Adifitrah: 2014). In Arabic, dhamir is categorized into two, which are dhamir rafa' dan dhamir nashab. Dhamir rafa' is a word that functions as subject and independent. Dhamir nashab is a word that functions as object and dependent or it should be attached to other words. In Arabic, there are twelve forms of dhamir (Adifitrah, 2014).

Table 1. Pronoun (dhamir rafa') in Arabic

\begin{tabular}{|c|c|c|c|}
\hline Category & Dhamir & Translation & Explanation \\
\hline \multirow[t]{2}{*}{$\begin{array}{l}\text { Mutakalim } \\
\text { (speaker) }\end{array}$} & Anā & $A k u$, saya & $\begin{array}{l}\text { Mufrad } \\
\text { Mudzakkar/muannats }\end{array}$ \\
\hline & Nahnu & Kami, kita & $\begin{array}{l}\text { Mufrad } \\
\text { Mudzakkar/muannats }\end{array}$ \\
\hline \multirow[t]{6}{*}{ Mukhathab } & Anta & Engkau & $\begin{array}{l}\text { Mufrad } \\
\text { Mudzakkar }\end{array}$ \\
\hline & Anti & Engkau & $\begin{array}{l}\text { Mufrad } \\
\text { Muannats }\end{array}$ \\
\hline & Antumā & Kaти berdua & $\begin{array}{l}\text { Mutsanna } \\
\text { Mudzakkar/muannats }\end{array}$ \\
\hline & Antum & Kalian & $\begin{array}{l}\text { Jamak } \\
\text { mudzakkar }\end{array}$ \\
\hline & Antunna & Kalian & $\begin{array}{l}\text { Jamak } \\
\text { Muannats }\end{array}$ \\
\hline & Huwa & Dia & $\begin{array}{l}\text { Mufrad } \\
\text { Mudzakkar }\end{array}$ \\
\hline \multirow[t]{4}{*}{$\begin{array}{l}\text { Ghaib } \\
\text { 'dibicarakan' }\end{array}$} & Hiya & Dia & $\begin{array}{l}\text { Mufrad } \\
\text { Muannats }\end{array}$ \\
\hline & humā & Mereka berdua & $\begin{array}{l}\text { Mutsanna } \\
\text { Mudzakkar/muannats }\end{array}$ \\
\hline & Hum & Mereka & $\begin{array}{l}\text { Jamak } \\
\text { mudzakkar }\end{array}$ \\
\hline & hunna & Mereka & $\begin{array}{l}\text { Jamak } \\
\text { Muannnats }\end{array}$ \\
\hline
\end{tabular}

Table 2. Dhamir rafa' and dhamir nashab in Arabic

\begin{tabular}{llll}
\hline Dhamir rafa' & Dhamir nashab & Dhamir rafa' & Dhamir nashab \\
\hline anā & $I$ & antunna & Kunna \\
\hline Nahnu & $\mathrm{Na}$ & Huwa & Hu \\
\hline Anta & $\mathrm{Ka}$ & hiya & Hã \\
\hline Anti & $\mathrm{Ki}$ & huma & Humā \\
\hline antum $\bar{a}$ & kumā & hum & Hum \\
\hline Antum & kum & hunna & Hunna \\
\hline
\end{tabular}

\subsection{Pronouns in Indonesian Language}

Pronoun is a word to replace a person or a thing. Personal pronoun is a pronoun to show the category of person such as $a k u$, engkau, dia (Alwi, 2007). Studies on pronoun (and/or personal pronoun) have been conducted by previous researcher. Among others are Kridalaksana (1986), Rohmadi et al (2012), Nurhayati (2009), Nur (2010), Rahman (2012). Their findings are the following:

According to Kridalaksana (1986) and Moeliono (1988) Indonesian pronoun is classified into two: definite and indefinite pronoun. Definite pronoun is used for definite reference that is personal pronoun. It consists of first, second, and third personal pronouns in both plural and singular forms. The following table is explaining Indonesian pronoun.

Table 3. Dhamir rafa' and dhamir nashab in Arabic

\begin{tabular}{lll}
\hline Category & Singular & Plural \\
\hline First person & saya, aku & kami, kita \\
\hline Second person & $\begin{array}{l}\text { kamu, engkau, } \\
\text { anda }\end{array}$ & $\begin{array}{l}\text { kalian, kamu sekalian, } \\
\text { anda sekalian }\end{array}$ \\
\hline Person & ia, dia, beliau & mereka, mereka semua \\
\hline
\end{tabular}


Indefinite pronoun is used to replace a person or a certain thing, such as sesuatu (something), seseorang (someone), barangsiapa 'whoever', siapa 'who', apa 'what', anu 'something else', masing-masing 'each', sendiri 'self' (Kridalaksana, 1986). Kridalaksana (1993) also stated that there are some types of pronoun such as demonstrative pronoun, disjunctive pronoun, objective pronoun, emphatic pronoun, exclusive personal pronoun, combined personal pronoun, inclusive personal pronoun, possessive pronoun, reflexive pronoun, relative pronoun, and reciprocal pronoun.

Similarly, Rohmadi et al (2012) classified pronoun into six categories: (1) personal pronoun; (2) demonstrative pronoun; (3) possessive pronoun; (4) interrogative pronoun; (5) relative pronoun; and (6) intermenetive pronoun. Rohmadi also added two other categories, which is based on the originality of the language: pronouns originated from Indonesian: aku 'I/me', engkau 'you', ia 'she/he', dia 'she/he', kami 'we', kamu 'you', and mereka 'they'; pronoun originated from other language (consists of address terms and third person pronoun influenced by Dutch) such as mendiang 'the late/deceased', beliau 'she/he' (respected), almarhum 'he-the late/deceased', and almarhumah 'she-the late/deceased'.

Nurhayati (2009) identified the use of personal pronoun used by teenagers in informal situations. She concluded that teenagers used different strategies to refer to first or second person, greetings, and referent noun. Some used one type of strategy all the times while some others used several strategies in accordance with the situation and purpose of the speech and the relations between the speaker and the listener. Second, there is a tendency to avoid the usage of clitics $k u$ 'my' and -mи 'your', to express possessiveness. Instead, teenagers used $a k u$ ' $\mathrm{I} / \mathrm{me}$ ' and kamu 'you'. Third, the strategy is chosen for several purposes such as to express group exclusiveness, to maintain intimacy, and to meet the need of communication. Fourth, the shift of strategy in referring or greeting is used by changing gue 'I' and loe 'you' into saya 'I' and kати 'you', and from saya 'I' and kати 'you' into the name of the speaker or the listener.

Setiawan (2012) conducted a study on personal pronoun as definite pronoun. He identified the definite personal pronoun used by the elementary school students in Yogyakarta. Sulistyowati (2011) has conducted a research on attributive phrases. She described the function, distribution, and relation of the meanings of attributive phrases in Indonesian.

Koban (2011) compared subject personal pronoun (SPP) of Turkish language spoken in Turkey and in New York City. Kummerow (2012) explained "third-person pronoun" by utilizing the cross-linguistics World Atlas of Language Structure database for data.

\subsection{Translation of Arabic Pronouns}

Some studies have been conducted on the usage of personal pronoun in the translation of the Quran. The studies relate to the interrogative sentences in Bahasa Indonesia version of translated Al-Quran. This result of this study shows (1) the form of questions in the translated version of the Qur'an are classified into the WH and yes-no question, (2) the function of question are categorize into three types of illocutionary acts: assertive, directive, and expressive, (3) the question in the translated version of the Qur'an are direct and indirect targets, and (4) the question can be categorize as rhetorical as well as arhetorical (Ainin, 2003). Some parts of the research result also discussed personal pronoun related to target questions. However, it did not specifically explain about the translation of pronoun from Arabic to Bahasa Indonesia.

\subsection{Studies on Personal Pronoun in Arabic}

The study on personal pronoun in Arabic focus on personal inflection related to the number of people and gender and in Arabic is conducted by Nur (2010: 78). This research focuses on the affix inflection to mark the person, grammatical category of number and gender on the Arabic verb form. There is a morphosyntax function that is expressed in the grammatical conformity between subject and verb or between adverbs and the subject in relation to number, person, and gender. A verb in perfect tense in Arabic is changed into fourteen forms through suffix inflection based on different person, number, and gender (Nur, 2010).

Table 4. Infkection Paradigm of Persona, Number of People, and Gender in Perfect Verbs in Arabic

\begin{tabular}{|c|c|c|c|c|}
\hline Persona & Gender & Number of people & Verb forms & $\begin{array}{l}\text { Equivalent meaning in } \\
\text { English }\end{array}$ \\
\hline \multirow{6}{*}{$\begin{array}{l}\text { Third- } \\
\text { person }\end{array}$} & \multirow[t]{3}{*}{ Masculine } & Singular & Kataba & He was written \\
\hline & & Dual & Katabā & The (two) have written \\
\hline & & Plural & Katabū & They have written \\
\hline & \multirow[t]{3}{*}{ Feminine } & Singular & Katabat & She has written \\
\hline & & Dual & Katabatā & The (two) have written \\
\hline & & Plural & Katabna & They have written \\
\hline \multirow{6}{*}{$\begin{array}{l}\text { Second- } \\
\text { person }\end{array}$} & \multirow[t]{3}{*}{ Masculine } & Singular & Katabta & You have written \\
\hline & & Dual & Katabtumā & You (two) have written \\
\hline & & Pulral & Katabtum & You have written \\
\hline & \multirow[t]{3}{*}{ Feminine } & Singular & Katabti & You have written \\
\hline & & Dual & Katabtumā & You (two) have written \\
\hline & & Pulral & Katabtunna & You have written \\
\hline \multirow{2}{*}{$\begin{array}{l}\text { First- } \\
\text { person }\end{array}$} & \multirow{2}{*}{$\begin{array}{l}\text { Masculine/ } \\
\text { Feminine }\end{array}$} & Singular & Katabtu & I have written \\
\hline & & Plural & Katabnā & We have written \\
\hline
\end{tabular}


Table 5. Inflection Paradigm of Persona, Number of People, and Gender in Imperfect Verbs in Arabic

\begin{tabular}{|c|c|c|c|c|}
\hline Persona & Gender & Number of people & Verb forms & Equivalent meaning in English \\
\hline \multirow{6}{*}{$\begin{array}{l}\text { Third- } \\
\text { person }\end{array}$} & \multirow[t]{3}{*}{ Masculine } & Singular & Yaktubu & $\mathrm{He}$ is wariting \\
\hline & & Dual & Yaktubāni & They (two) are writing \\
\hline & & Plural & Yatubūna & They are writing \\
\hline & \multirow[t]{3}{*}{ Feminine } & Singular & Taktubu & She is writing \\
\hline & & Dual & Taktuāni & They (two) are writing \\
\hline & & Pulral & Yaktubna & They are writing \\
\hline \multirow{6}{*}{$\begin{array}{l}\text { Second- } \\
\text { person }\end{array}$} & \multirow[t]{3}{*}{ Masculine } & Singular & taktubu & You are writing \\
\hline & & Dual & Taktubāni & You (two) are writing \\
\hline & & Pulral & Taktubūna & You are writing \\
\hline & \multirow[t]{3}{*}{ Feminine } & Singular & Taktubīna & You are writing \\
\hline & & Dual & Taktubāni & You (two) are writing \\
\hline & & Pulral & Taktubna & You are writing \\
\hline \multirow[t]{2}{*}{$\begin{array}{l}\text { First- } \\
\text { person }\end{array}$} & Masculine & Singular & Aktubu & I am writing \\
\hline & Feminine & Plural & Naktubu & We are writing \\
\hline
\end{tabular}

Munifatullah (2010) compared the personal pronoun used in Arabic and Minangkabau language in relation to grammatical category of number, gender, and verb. She concluded that in Minangkabau, social variable (e.g. age, gender, occupation, and education background) and functional variable (relations among speakers, level of formality, genre, topics, and speech plot) influence the use of personal pronoun.

Nevertheless, their studies only discussed personal pronoun in single unit instead of in lingual unit and there are not the personal pronoun in the Quran translation. In fact, personal pronouns found in the Quran are not only in the form of word, but also phrases. The problem investigated in this research is whether phrases can be categorized as pronouns or not. This research will elaborate the linguistic unit containing personal pronoun in the translation of the Quran.

In some studies he conducted, Manns (2012) stated that the existence of personal pronoun in Arabic is used as one variety of first person personal pronoun of Bahasa Indonesia user. The pronouns he mentioned are antum, ana, and ane.

Some studies regarding personal pronoun in Arabic do not specifically focus on personal pronoun used by the translated text of Al-Quran. Thus, it is important to conducted further study on the translation of personal pronoun in the translated text of Al-Quran in Bahasa Indonesia.

\subsection{Recent Studies about Qur'an Language}

Several studies presented various aspects related to the translation of the Quran. For example, moralities described in the Quran to prevent disintegration (Markhamah, 2002); gender in the translation of the Quran (Markhamah, 2003a, 2003b); Language Ethics in Islam: Sociolinguistics Study (Sabardila et al., 2003; 2004), development of the concept of speech participants in religious text (Markhamah, 2007; 2008; 2009a); politeness in the translation of the Quran (Markhamah and Sabardila, 2009), Conformity of the Function, Category, and Role in the translation of the Quran (Markhamah and Atiqa Sabardila, 2010a); Passive voice in the clauses found in the translation of the Quran (Markhamah and Atiqa Sabardila, 2010b); Developing Teaching and Learning Materials on Syntax based on the Quran (Markhamah, 2011; 2012; 2013). Several other studies have been conducted in relation to gender aspect in the Quran or in Islam, such as the studies conducted by Umar (2001), Azis (2002), Faisal (2002), Engineer (2002), and Maslamah (2002).

Study regarding Al-Quran was also conducted by Zaid (2011). In his article, Zaid stated that "In this vein, the paper considers available research evidence documenting the relationship between language learnig the Qur'an and scholastic achievement in other school subjects. Research has indicated that the Qur'an can be a strong source for teachig thinking method and creativity."

In addition, in some parts of his book, Rahardjo (2008) discussed the perspective of Quran towards language and contextualization of Al-Quran. He studied Al-Quran from its linguistic perspective and its relation between language and Al-Quran, and so on. However, he did not specifically mention the translation of personal pronoun.

Based on the review result of some studies, which are study of pronoun in general, pronoun in Arabic, translation of AlQuran, and other studies of Al-Quran, there is still no specific research on the translation of personal pronoun in translated text of Al-Quran in Bahasa Indonesia. Therefore, it will be important to conduct this research. The result of this research would be a significant study reference for the translation of Al-Quran into Bahasa Indonesia in particular, and other languages in general. Moreover, the findings of this study would be the basis for translators to pay attention on the accuracy of translation, especially on the translation of personal pronoun. The difference between the translations of Al-Quran from Arabic to Bahsa Indonesia could ultimately trigger misinterpretation of Al-Quran content, while AlQuran is an important guide of life for Muslims around the world. The inaccuracy of translation will cause misinterpretation in understanding the content of Al-Quran, which will also cause inaccuracy in practicing the teachings.

The present study attempts to identify how personal pronouns in Qur'an are translated into Indonesian language. The 
analysis is focused on (1) the influence of number and gender to the translation, (2) translation of honorific pronouns. The study of personal pronoun in the translated text of Al-Quran in Bahasa Indonesia does not regard the pronoun position as subject or object.

\section{Research Method}

This present study belongs to comparative-descriptive-qualitative study. This study depicts the use of pronoun in the Indonesian translation of Al-qur'an. Furthermore, it is compared to the original version of Al-Qur'an, i.e. Arabic language. The objects of the research are personal pronouns and the data are all linguistic units consisting of personal pronouns in the Indonesian translation of Quran with its original-Arabic version. The data are collected using content analysis. The data of the the research are all lingual units containing personal pronoun in the translation of the Quran. The data sources of this current study was issued by Khadim Al Harmain asy Syarifain (Second Servant of the Mecca); Raja Fahd ibn 'Abd al 'Aziz Al Sa'ud. The data are collected from the verses containing the referred linguistic aspects.

This study employed an observation and documentation method. The techniques used are simak bebas libat cakap (uninvolved conversation observation technique) in order to observe the text of the Quran translation and teknik catat (note taking) to note the usage of lingual unit containing personal pronoun in the Quran translation.

Identification method is conducted by using measurement that is separated from and is not the part of the observed language. Referential identification, is used to analyze the differences and similarities of the Arabic, Indonesian language, and Javanese Language in the translation of the Quran. Translational identification is also used in the research. Distributional method is used to identify the lingual unit in the translation of the Quran, either the similarities or the differences of the referred languages. Comparative and distributional methods are employed to analyze the data.

Finally, the procedure in conducting this present study is by (1) identifying the utilization of personal pronoun in the Indonesian translation of Al-Qur'an; (2) after it is identified, this study compares the personal pronoun to the original text of Al-Qur'an (in Arabic language); (3) the result of this comparison, particularly the personal pronoun which contains differences between Indonesian and Arabic language are presented in this paper. However, the use of pronoun which does not contains confirm any differences is not presented in the current paper.

\section{Data Finding and Discussion}

Based on the analysis, this study formulates its result and the discussion in this section. The result of the study is directly followed by its discussion in order to facilitate the readers in understanding the entire of the study itself. This section is established by (1) influence of number of gender and to pronoun translation; and (2) translation of honorific pronouns.

\subsection{Influence of Number of Gender and to Pronoun Translation}

There are some forms of translated pronouns from Arabic to Bahasa Indonesia found in Al-Qur'an; they are included in the following table.

Table 6. Personal Pronouns in Al-Qur'an

\begin{tabular}{|c|c|c|c|c|}
\hline \multicolumn{3}{|c|}{ Source Text } & Pronomina & Target Text \\
\hline \multirow{4}{*}{ Singular } & & 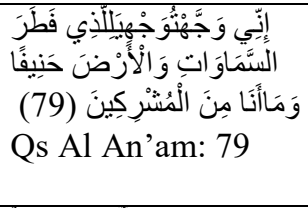 & $\begin{array}{l}\text { Wajahtutu is dependent to the } \\
\text { verb, wajhii is a pronoun that is } \\
\text { dependent to the noun, Ana. }\end{array}$ & $\begin{array}{l}\text { aku menghadapkan wajahku } \\
\text { untuk yang menciptakan langit } \\
\text { dan bumi, lurus dalam } \\
\text { kebenaran, dan tidaklah aku, } \\
\text { termasuk orang yang musyrik. }\end{array}$ \\
\hline & Male & 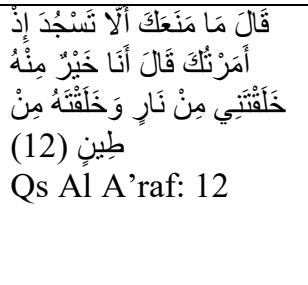 & $\begin{array}{l}\text { Ana, kholaqtani i connected to } \\
\text { fi'il }\end{array}$ & $\begin{array}{l}\text { Apa yang menghalangimu } \\
\text { sampai engkau tidak suhud, } \\
\text { ketika aku perintahkan engkau, } \\
\text { dia berkata aku lebih baik dari } \\
\text { dia, engkau ciptakan aku dari } \\
\text { api dan engaku ciptakan dia } \\
\text { dari tanah. }\end{array}$ \\
\hline & \multirow[t]{2}{*}{ Female } & 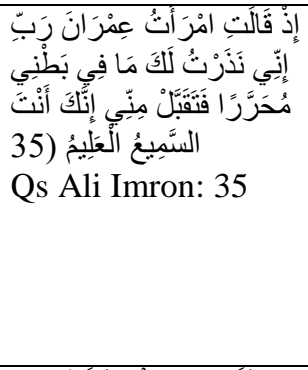 & $\begin{array}{l}\text { Rabi (i) pronoun connected to } \\
\text { Rabb, inni, connected to inna, } \\
\text { nadzartu, (tu), bathnii (i) } \\
\text { connected to minnii, (ii) } \\
\text { connected to the conjunction min. }\end{array}$ & $\begin{array}{l}\text { Ingatlah ketika istinya "imron } \\
\text { berkata, wahai rabbku } \\
\text { sesunggunya aku, aku } \\
\text { bernadzar, untukmu, apa yang } \\
\text { ada dalam perutku, sebagai } \\
\text { orang yang dibebaskan untuk } \\
\text { khidmah, maka terimalah } \\
\text { dariku, sesungguh engkau maha } \\
\text { Mendengar Maha mengetahui. }\end{array}$ \\
\hline & & 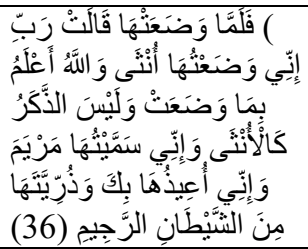 & $\begin{array}{l}\text { Wadh'atu, (tu), inni, connected to } \\
\text { inna, sammaituha, (tu) connected } \\
\text { to verb. Inni(i) connected to inna, } \\
\text { u'idzu, (u) a sign that is connected } \\
\text { to verb, }\end{array}$ & $\begin{array}{l}\text { Takala dia melahirkannya, dia } \\
\text { berkata, wahai rabbku, } \\
\text { sesungguhnya } \\
\text { melahirkannya sebagai putri, } \\
\text { dan Allah lebih mengetahui } \\
\text { dengan apa yang dia }\end{array}$ \\
\hline
\end{tabular}



sama dengan perempuan, dan sesungguhnya aku, aku menamainya, maryam, dam aku memperlindungkan dia dan keturunannya dari seta yang terkutuk.

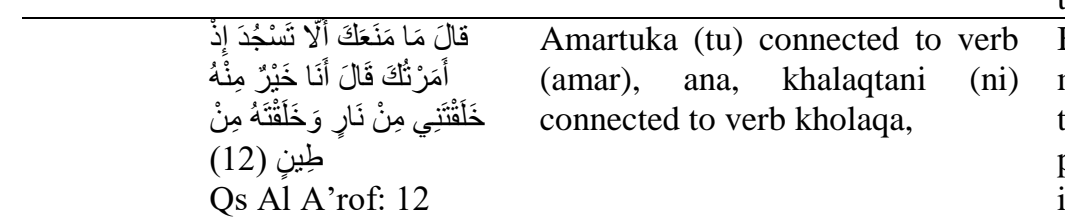
Berkata (Dia) apa yang

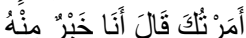
طِينٍ (12)

Qs Al A'rof: 12 menghalangi sampai engkau tidak sujud ketika aku perintahkan engkau, berkata iblis, aku lebih baik dari dia engkau ciptakan aku dari api Neutral dan engaku ciptakan dia dari tanah

\begin{tabular}{|c|c|}
\hline 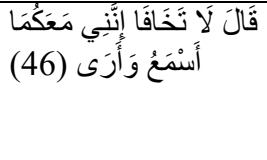 & $\begin{array}{l}\text { Innani, (ni) connected to kata } \\
\text { inna, asma'u, (marker "a" } \\
\text { connected to sami'a wa ara } \\
\text { (connected to the verb "ra'a"). }\end{array}$ \\
\hline
\end{tabular}

Berfirman Allah: janganlah kalian berdua takut, sesungguhnya aku bersama kalian berdua aku mendengar dan aku melihat

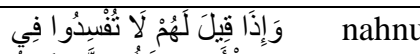
Jika dikatakan keda mereka

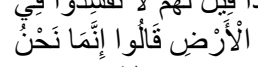
مُصنِلْحُونَ (11) Qs Al Baqarah: 11 jangan berbuat kerusakan di bumi, mereka berkata, tiada lain kamiberbuat perbaikan

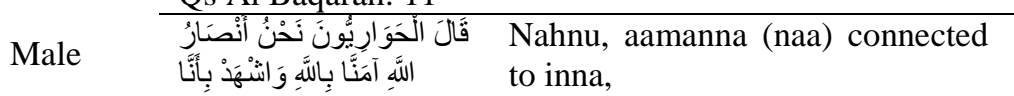
Hawariyyun berkata: kami

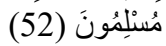
penolong penolong Allah, kami

Qs Ali Imron: 52 beriman kepada Allah, dan saksikan sesungguhnya kamimenyerahkan diri kepada Allah.

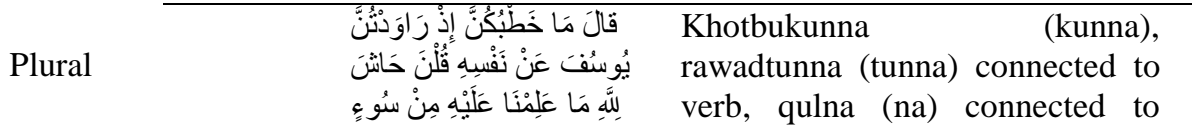
Apa urusan kalian ketika kalian Qs Yusuf: 51 verb, 'alimnaa (naa) connected to verb. menggoda Yusuf akan dirinya, mereka berkata : maha suci Allah tidaklah kami mengetahi tentang dia dari keburukan

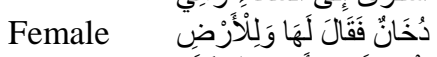
Aatinaa (naa) connected to verb Kemudian dia menuju ke langit dan dia bumi dalam kondisi asap, berkatalah kepadanya, dan kepada Bumi datanglah engkau berdua (bumi langit) dalam kondisi taat atau terpaksa, keduanya berkata, kami datang dalam kondisi taat.

\begin{tabular}{|c|c|c|c|c|}
\hline \multirow[t]{2}{*}{ Dualis } & & 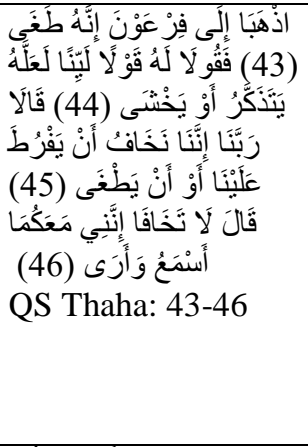 & $\begin{array}{l}\text { Idzhabaa, (aa) connected to verb, } \\
\text { quulaa (aa) connected to verb, } \\
\text { qaalaa (aa) connected to verb, } \\
\text { rabbanaa (naa) connected to the } \\
\text { word rabba, innanaa (naa) } \\
\text { connected to word inna, nakhofu, } \\
\text { connected to the verb khafa, } \\
\text { 'alainaa (naa) connected to prefix } \\
\text { 'ala, }\end{array}$ & $\begin{array}{l}\text { Pergilah kalian berdua kepada } \\
\text { fir'aun sesungguhnya dia } \\
\text { melampaui batas, katakanlah } \\
\text { kalian berdua kepadanya, } \\
\text { perkataan yang lembut } \\
\text { barangkali dia mengmabil } \\
\text { pelajaran atau takut, kedua dua } \\
\text { mengaatakan wahai rabb kami } \\
\text { sesungguhnya kami takut akan } \\
\text { berbuat dhalim atas kami atau } \\
\text { melampui batas/ }\end{array}$ \\
\hline & Mal & 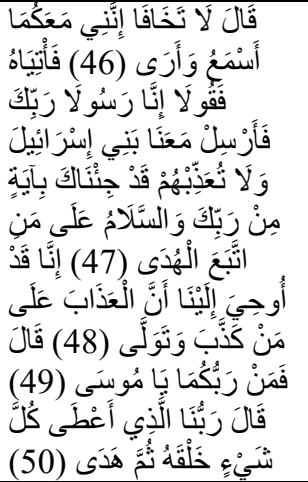 & $\begin{array}{l}\text { Takhofaa, (aa) connected to verb, } \\
\text { ma'akumaa (kuma) connected to } \\
\text { the word ma'a, fa'tiyaahu (yaa) } \\
\text { connected to ya'ti, faquulaa (aa) } \\
\text { connected to verb qaala the it is } \\
\text { changed to the imperative verb of } \\
\text { two people quulaa, innaa } \\
\text { (connected to kata inna, rasuulaa, } \\
\text { (aa) connected to rasuul, ma'aana } \\
\text { (naa) (kami 'we') which refers to } \\
\text { two people, ji'naaka (naa) } \\
\text { connected to jaa'a, since it is }\end{array}$ & $\begin{array}{l}\text { Berkata: janglah Kalian Berdua } \\
\text { takut, sesungguh aku bersama } \\
\text { kalian berdua mendengar dan } \\
\text { melihat, datangilah kalian } \\
\text { berdua kepadanya dan } \\
\text { katakanlah kalian berdua } \\
\text { sesungguhnya kami dua utusan } \\
\text { Rabb engkau, maka lepaskanlah } \\
\text { bani isroil bersama kami dan } \\
\text { jangan engkau siksa mereka, } \\
\text { kami telah datang dengan ayat } \\
\text { dari rabbmu, dan kesejahteraan }\end{array}$ \\
\hline
\end{tabular}


Qs Thaha: 46-50 plural becomes ji'naa, ilaana bagi yang mengikuti petunjuk, (connected to prefix ilaa, sesungguhnya kami telah rabbukuma, (kumaa) connected to diwahyukan kepada kami the word rabb. sesungguhnya adzab atas orang yang mendustakan dan berpaling.fir'aun berkata: siapa rabb kalian berdua, wahai Musa, musa berkata: rabb kami yang telah memberikan segala sesuatu ciptaannya kemudian menunjuki.

\begin{tabular}{|c|c|}
\hline 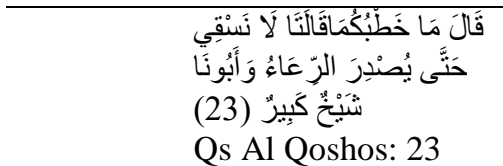 & $\begin{array}{l}\text { Khotbukuma (kuma) connected to } \\
\text { word khotbu, qaalataa (taa) } \\
\text { connected to verb qaala, laa nasqi } \\
\text { (nasqi) melekat dengan verb, }\end{array}$ \\
\hline
\end{tabular}

Female Berkata Musa: apa urusan kalian berdua, keduanya berkata: kami tidak dapat memberi minum sehingga para pengembala membawa pulang gembalaannya, sedang ayah kami orang tua renta.

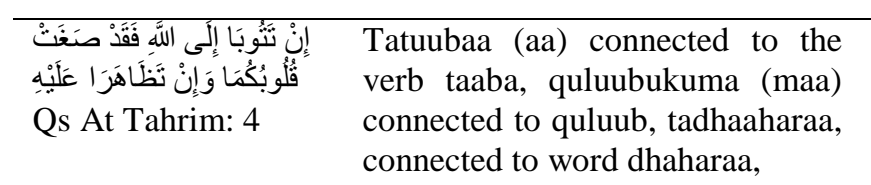

Jika engkau berdua bertaubat kepada Allah sungguh telah tunduk hati kalian berdua, dan jika kalian berdua berkonspirasi atasnya

\begin{tabular}{|c|c|}
\hline 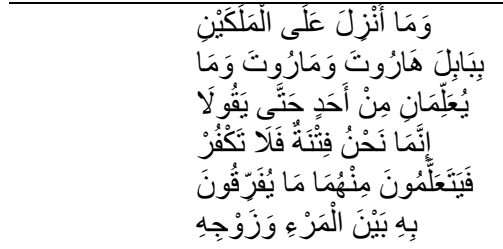 & $\begin{array}{l}\text { Yu'allimaani (aani) connected to } \\
\text { verb ya'allim, yaquulaa, } \\
\text { connected to verb qaala, nahnu, } \\
\text { minhuma (huma) connected to } \\
\text { prefix min. }\end{array}$ \\
\hline
\end{tabular}

Qs Al Baqarah:102

Dan apa yang diturunkan kepada dua malaikat di babil yaitu harut dan marut, dan tidaklah keduanya mengajarkan seseorang sehingga keduanya berkata, tiada lain kami ini fitnah maka janganlah engkau kafir lantas mereka belajar dari keduanya, apa yaang mereka gunakan untuk memisahkan seseorang dari istrinya.

Netral

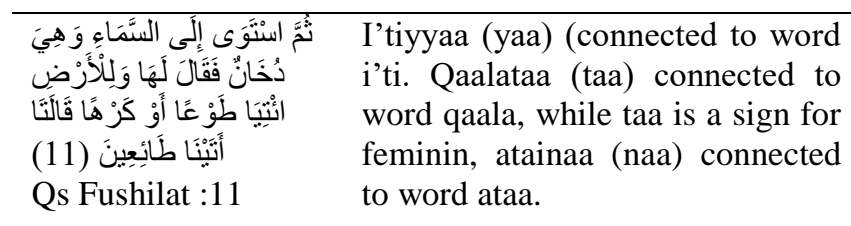

Kemudian menuju ke langit dan dia dalam kondisi asap lantas berfirman kepadanya, dan kepada bumi datanglah engkau berdua, dalam kondisi taat atau terpaksa, keduanya berkata: kami datang dalam kondisi taat.

The above findings (in Table 6) note that personal pronoun in Arabic is highly influenced by other forms in its environment. This is significantly different to Bahasa Indonesia. Personal pronoun in Bahasa Indonesia is an independent form, except those which are klitik.

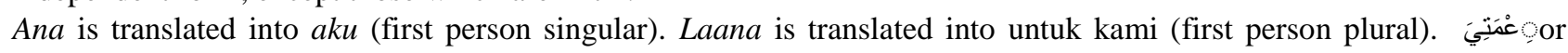
nikmatiya is translated into nikmatku. Waanni is translated into dan bahwa Aku (first person singular).

Generally, first person pronoun is distinguished into singular and plural. $A k u$ ' $\mathrm{I}$ ' is used to show first person singular and $k a m i$ 'we' is for first person plural. In Indonesian, the word aku is used to refer to the first person. However, if the first person singular refers to Allah, then the first letter of the word $a k u$ should be written in capital letter, that is $A k u$.

Kami is translated differently. In Indonesian, kami is used to show first person plural, while in the Quran, kami may refer to either singular or plural, depending on the context of the sentence.

Al Baqarah (2): 70

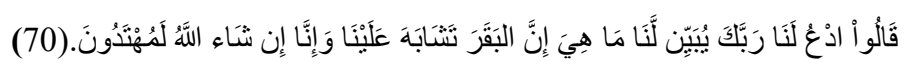

"Mereka berkata: "Mohonkanlah kepada Tuhanmu untuk kami agar Dia menerangkan kepada kami bagaimana hakikat sapi betina itu, karena sesungguhnya sapi itu (masih) samar bagi kami dan Sesungguhnya kami insya Allah akan mendapat petunjuk (untuk memperoleh sapi itu)."

In this verse, pronoun kami is used to show first person plural, for it refers to Musa's people. Similar examples can be found in other verses, such as 4: 46, 150; $5: 41 ; 24: 18,51$, and so on.

In other verses, in Arabic جَعَلْنَاwhich is in plural form, is translated into Bahasa Indonesia kami, which is used for first person singular, as can be seen in 6:112; 7: 161-2;11:69, and so on.

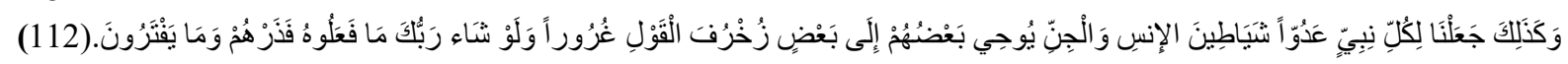


"Dan demikian Kami jadikan bagi tiap-tiap nabi musuh, yaitu syaitan-syaitan (dari jenis) manusia dan (dari jenis) jin, sebagian mereka membisikkan kepada sebagian yang lain perkataan-perkataan yang indah-indah untuk menipu (manusia). Seandainya Tuhanmu menghendaki, niscaya mereka tidak mengerjakannya, maka tinggalkanlah mereka dan apa yang mereka ada-adakan."

The word Kami refers to singular if it is used to refer to Allah, because he is the only one. The Arabic first person singular is also translated into $a k u$.

Both Kami (as a singular pronoun) and Aku refer to Allah. Consider the verses of Al-Hijr 16, 17, 19, 20, 21, 22, 23, and 25. In those examples, kami is used for singular pronoun.

Al Hijr (15): 16

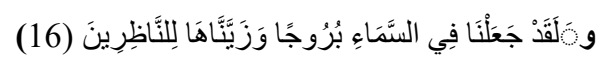

"Dan sesungguhnya Kami telah menciptakan gugusan bintang-bintang (di langit) dan Kami telah menghiasi langit itu bagi orang-orang yang memandangnya"

Al Hijr (15): 17

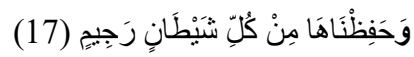

'Dan Kami menjaganya dari tiap-tiap syaetan yang terkutuk'

Al Hijr (15): 19

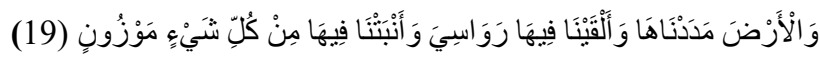

"Dan Kami telah menghamparkan bumi dan menjadikan padanya gunung-gunung dan Kami tumbuhkan padanya segala sesuatu menurut ukuran".

"Dan Kami telah menjadikan untukmu di bumi keperluan-keperluan hidup dan (Kami menciptakan pula) makhlukmakhluk yang kamu sekali-kali bukan pemberi rezeki padanya".

In other verses, the first person singular to refer to God is used.

"Dan ingatlah ketika Tuhanmu berfirman kepada para Malaikut: Sesungguhnya Aku akan menciptakan seorang manusia dari tanah liat kering (yang berasal) dari lumpur hitam yang diberi bentuk".

"Maka apabila Aku telah menyempurnakan kejadiannya dan telah meniupkan kedalamnya ruh (ciptaaan)-Ku, maka tunduklah kamu kepadanya dengan bersujud”.

"Kabarkanlah kepada hamba-hamb-Ku, bahwa sesungguhnya Akulah yang Maha Pengampun lagi Maha Penyayang”. [Al-Hijr (15): 49].

"Dan bahwa sesungguhnya azab-Ku adalah azab yang sangat pedih". [Al-Hijr (15): 50].

From these examples, it is worth questioning on (1) When and in what context is the pronoun referent for Allah/God should be translated into plural form Kami (we), and when is should be translated into singular Aku (I)?; (2) Is there any difference to refer to Allah in Arabic?; (3) considering the Indonesian first person singular, Aku (I)has similar meaning with saya(I) then why has saya never been used to refer to Allah or human or other creatures in the Indonesian translation of the Quran?

First person plural Kami has similar meaning with the Arabic word Anzalna to show the greatness of Allah, the One.

The use of $a k u$ and kami is, indeed, following the structure of the Arabic language. The Arabic nahnu means kami and ana means $a k u$. Pronoun can be attached into fi'il (verb), for example in nafakhtu fiihi min ruuhi 'I breathed from My soul'. The aesthetic aspect of the Arabic language is maintained in the Indonesian translation of the Quran. For example, to show the excellence of the king's decree, the Arabian says "nahnu malik Saudi", which can be translated into Indonesian 'kami raja Saudi" 'we are the king of Saudi'. In similar way, if the Arabic uses first person singular, then the translation should use first person singular.

As for the use of $A k u$ instead of Saya, it is possible that to refer to God, it is more appropriate to use aku. Saya may be used to refer to human. Nonetheless, Arabic uses ana to refer to aku and saya. Otherwise, singular form may be attached to the verb as in the previous example Nafakhtu 'I breathed'. First person singular saya 'I', according to Rokhmadi et al (2012), is categorized as non-original in Indonesian personal pronoun.

Through interpretation, it turned out that $A k u$ and kami - though both refer to Allah - is used differently. In the creation of Isa, Allah is translated into Aku, while in the creation of Adam's children, Allah is translated into Kami. It is explained that when the creation does not involve human's intervention, $A k u$ is used. In contrast, Kami is used when the creation involves human's intervention.

In the Indonesian translation of the Quran, second person singular and plural has the same form, that is kamu. Dual noun can be seen explicitly in the translation.

Al Baqaroh (2): 11

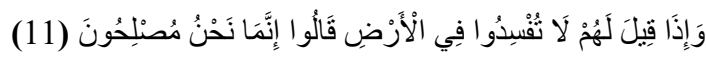

"Dan bila dikatakan kepada mereka: janganlahkamu membuat kerusakan di muka bumi, mereka menjawab: sesungguhnya kami orang-orang yang mengadakan perbaikan" 
In the translation, pronoun kamu is not followed by sekalian to indicate plural pronoun. The literal meaning is janganlah kalian, or janganlah kamu sekalian. The omission of sekalian is probably done because the sentence that follows has explained the plural noun: "Mereka menjawab: sesungguhnya kami orang-orang yang mengadakan perbaikan.". It has orang-orang, which indicates plural noun in Indonesian. "Apabila dikatakan kepada mereka: berimanlah kamu sebagaimana orang-orang lain telah beriman Mereka menjawab: akankah kami beriman sebagaimana orang-orang yang bodoh itu telah beriman?" [Al Baqarah (2):13].

Similar to the previous verse, kати is used to refer to second person plural, without being followed by sekalian. The reason is that the word кати has clearly indicated that the referent is plural. In addition, the word sekalian has been represented by the phrase akankah kami and dikatakan kepada mereka. The direct sentence that uses mereka help to explain that the pronoun кати refers to second person plural.

"Wahai manusia, sembahlah tuhanmu yang telah menciptakan kamu dan orang sebelummu agar kamu bertakwa" [AlBaqarah (2): 21].

Again, we see that the word sekalian has been omitted, whereas the Arabic word annas is plural. The literal translation is kalian sетиа. The assumption is that manusia can be used to indicate plural noun. However, in certain context, for example in Dia adalah manusia yang sempurna', the word manusia indicates singular noun. The existence of the word sempurna restricts the meaning and thus manusia becomes singular.

Al Baqarah 22:

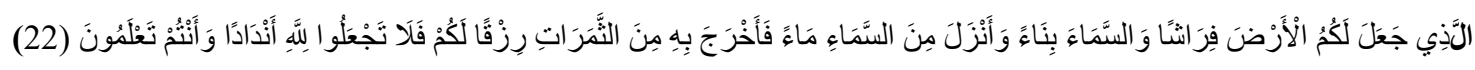

"Dialah yang yang menjadikan bumi sebagai hamparan bagimu, dan langit sebagai atap dan Dia menurunkan air hujan dari langit, lalu Dia menghasilkan dengan hujan itu buah-buahan sebagai rizki untukmu. Karena itu janganlah mengadakan sekutu-sekutu bagi Allah padahal kamu mengetahui”.

The singular forms such as bagimu, untukmu, janganlah kати are all used to indicate plural noun. It is probably done to make the sentence more efficient.

Al Baqarah (2): 23

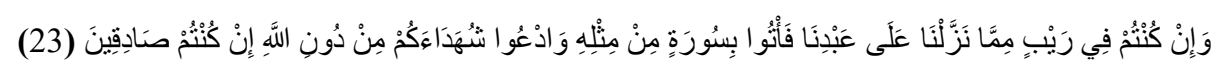

"Dan jika kamu (tetap) dalam keraguan tentang al-qur'an yang Kami wahyukan kepada hamba Kami (muhammad). Buatlah satu surat (saja) yang semisal Al-Qur'an itu dan ajaklah penolong-penolongmu selain Allah jika kamu orangorang yang benar" "Maka jika kamu tidak dapat membuatnya dan pasti kamu tidak akan dapat membuatnya peliharalah dirimu dari neraka yang bahan bakarnya manusia dan batu"

The use of kати 'you' to indicate both singular and plural noun, such as the translation of inlam taf'alu, wa lan taf'aluu, does not really explain the singular and plural noun. It should be translated into kamu for singular, and kamu sekalian for plural.

Al Baqarah (2): 38

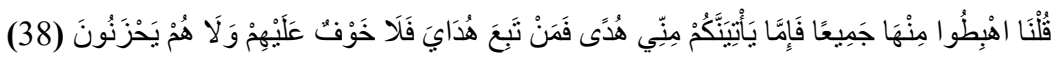

"Kami berfirman: turunlah kamu semua dari sorga itu! Kemudian jika datang petunjukku kepadamu maka barang siapa yang mengikuti petunjukku niscaya tidak ada kekhwatiran atas mereka dan tidak pula mereka bersedih hati"

The verse above explained Allah's order to Adam and Eve to leave heaven and start a new life on earth. And thus begin the conflicts among Adam and all his descendants. Plural pronoun is inserted to the verb qulna ihbithu or Turunlah kalian sетиа. Kalian sетиа 'all of you' may include Adam, Eve, and Satan. Therefore, the pronoun kalian 'you (in plural)' can be called essential plural. If it refers to Adam and Eve, then it is acceptable in the system of Arabic language.

On the above examples, kати is used to indicate plural noun, while in the following, pronoun kaти is used to indicate singular pronoun.

Al Baqarah (2): 204

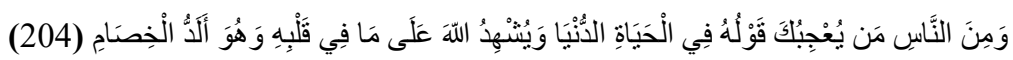

"Dan di antara manusia ada orang yang ucapannya tentang kehidupan dunia menarik hatimu dan dipersaksikannya kepada Allah (atas kebenaran) isi hatinya, padahal ia adalah penantang yang paling keras.

The second person $-т и$ (which is an enclitic) is derived from the word kamu which refers to the Prophet Muhammad SAW and it is singular. Similar example can be seen in An Nisaa' (4): 63, in which enclitic $-m u$ also refers to the Prophet (Hatta, 2009: 88).

An Nisa (4): 63

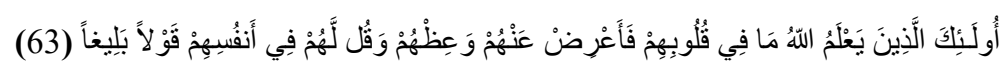

"Mereka itu adalah orang-orang yang Allah mengetahui apa yang di dalam hati mereka. Karena itu, berpalinglah kaтu dari mereka, dan berilah mereka pelajaran, dan katakanlah kepada mereka perkataan yang berbekas pada jiwa merek" 
Those examples show that the Indonesian second person kamu and enclitic $-m u$ may be used to refer to singular or plural noun. Nevertheless, the Indonesian system that only has singular and plural pronoun may cause difficulty to the readers who are not familiar with Arabic.

Second person singular and plural is different from the second person pronoun to show dual number. It can be seen from the attribute "... berdua" in the translation. Consider Thaaha (20): 42, 43, 44, 45 below.

Thaha (20): 42

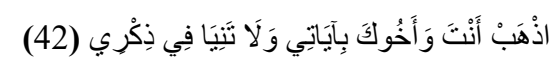

"Pergilah kamu beserta saudaramu dengan membawa ayat-ayat-Ku, dan janganlah kamuberdua lalai dalam mengingat-Ku"

"Pergilah kamu berdua kepada Firaun, sesungguhnya dia telah melampaui batas;"

Thaahaa (20): 44

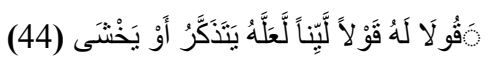

"maka berbicaralah kamuberdua kepadanya dengan kata-kata yang lemah lembut, mudah-mudahan ia ia ingat atau takut".)

Thaha (20): 45

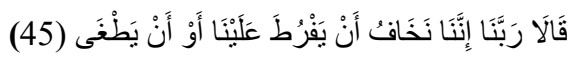

"Berkatalah merekaberdua: "Ya Tuhan kami, sesungguhnya kami khawatir bahwa ia akan segera menyiksa kami atau akan bertambah melampaui batas"

In (2) - (3), we can see the phrase kamu berdua, which is the translation of walaataniyaa. In (3) there is also kamu berdua, which is the translation of faquula ('bicaralah kamu berdua') (Hatta, 2009, p. 314). To refer to dual number, the additional word berdua is used explicitly, while second person singular and plural has similar form: kamu.

From the context, example (1) has shown that the word kamu (In dan janganlah kamu berdua lalai dalam mengingat $K u$ ) has sufficiently expressed kamu beserta saudaramu, but the translator added the word berdua to emphasize the dual number, to distinguish it from the singular and plural form. The emphasis is strengthened by Thaaha (20): 32, "And let him share my task", which shows that Allah has given Musa and Harun the same task and they have to spread the dakwah together.

Based on the analyzed data, there are four findings that are suitable with the purposes of this article. Below are the results and discussion of the research on the use of personal pronoun in the translation of the Quran.

From the gender aspect, Indonesian and Arabic are different. In Indonesian, the word $i a$ can be used for both man and woman, while in Arabic, the personal pronoun is different.

Al Qashah (28):7

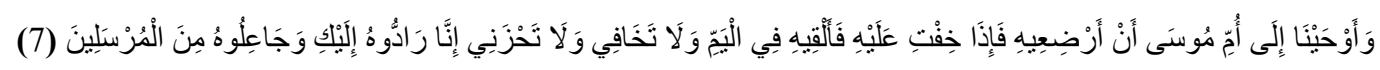

"Dan kami ilhamkan kepada ibu Musa, "susuilah dia dan apabila kamu khawatir terhadapnya maka jatuhkanlah dia ke sungai nil dan janganlah kamu khawatir dan jangan pula bersedih hati"

The word ardhi' 'iihi (Arabic) is an imperative for female, while adhi' $i h$ is an imperative for male. In Indonesian, it is enough to say susuilah dia, instead of susui kaтu perempuan dia (Musa). Another example is shown by the word khifti, which means "engkau perempuan takut", and khifta, which means "engkau laki-laki takut". The Indonesian translation for both khifti and khifta is kamu takut/khawatir.

Similar example is shown by the following verse,

"Dan berkatalah istri Fir'aun (ia) adalah penyejuk mata hati bagiku."

The Arabic mentioned wa qaalat (Ind: dia perempuan berkata [Eng: she said]), but the Indonesian translated it into dia berkata.

Similar example can be seen in the following verse:

"dan kami cegah Musa kepada perempuan-perempuan yang mau menyusui (nya) sebelum itu. Maka berkatalah saudara musa.."

In the Arabic text, it is written faqaalat, which means "maka dia perempuan(saudari Musa) berkata...". The literal translation for the phrase is saudara perempuan Musa or Saudari Musa.

In the Arabic text, the word fiihi, which means 'padanya'(to it), does not distinguish the personal pronoun for male and is therefore neutral. It is translated into '-nya' or 'itu.'

Al Baqarah (2): 2

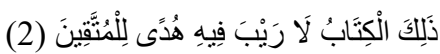

"Kitab Al-Qur'an ini tidak ada keraguan padanya, petunjuk bagi mereka yang bertaqwa."

Al Baqarah (2): 17

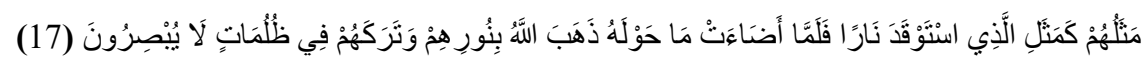


"Perumpamaan mereka adalah seperti orang yang menyalakan api maka setelah api itu menerangi sekelilingnya Allah hilangkan cahaya yang menyinari mereka dan membiarkan mereka dalam kegelapan, tidak melihat"

In Arabic, ma haulahu is similar to Arabic personal pronoun for male, but since it is a neutral pronoun, it is translated into -nya in Indonesian. Similar example can be seen in [Al Baqarah (2): 17]; [QS Ali Imron (3):2].

Al Baqarah (2) 17

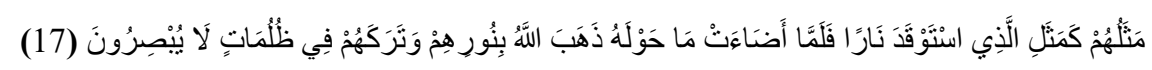

"Perumpamaan mereka adalah seperti orang yang menyalakan api maka setelah api itu menerangi sekelilingnya Allah hilangkan cahaya yang menyinari mereka dan membiarkan mereka dalam kegelapan, tidak melihat"

It can be seen from this example that translating the neutral personal pronoun into itu or -nya is easier to understand than if not using pronoun.

Ali $\operatorname{Imron}(3): 2$

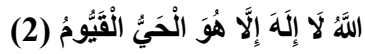

"Allah tidak ada Tuhan (yang berhak disembah) melainkan Dia Yang hidup kekal lagi terus-menerus mengurus makhluq-Nya".

The word Dia in (6) refers to Allah as the translation of huwa, the third singular pronoun for male.

Al Baqarah (2): 67

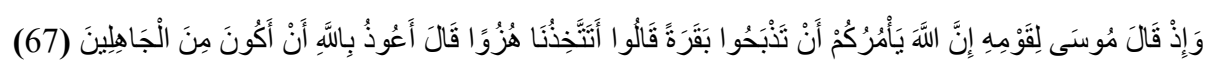

"Dan ingatlah, ketika Musa berkata kepada kaum-Nya: sesungguhnya Allah menyuruh kamu menyembelih seekor sapi betina, mereka berkata: apakah kamu hendak menjadikan kami buah ejekan, Musa menjawab: Aku berlindung kepada Allah agar tidak menjadi salah seorang dari orang orang jahil.

The Arabic word qoumihi (Ind: kaumNya) is a third person singular that is translated into "Nya" in Indonesian for language aesthetic.

Al Baqarah (2): 66

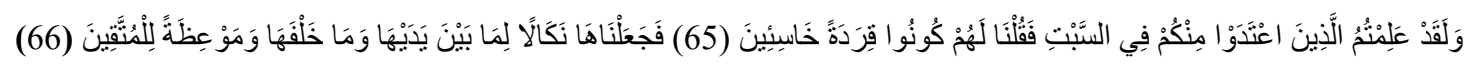

"Maka jadikan yang demikian itu peringatan bagi orang orang di masa itu, dan bagi mereka yang datang kemudian, serta merta menjadi pelajaran bagi orang orang yang bertaqwa".

In translating tense, there is no difference in terms of personal pronoun. In terms of tense, Indonesian does not differentiate the personal pronoun that is used.

"Dan jika kamu (tetap) dalam keraguan tentang Al-Qur'an yang Kami wahyukan kepada hamba Kami (Muhammad). Buatlah satu surat (saja) yang semisal Al-Qur'an itu dan ajaklah penolong-penolongmu selain Allah. jikakamu orangorang yang benar [Al Baqarah (2): 23].

Pronoun kamu explains the doubt of the past and a demand to conduct certain action in the future. In both past and present, the pronoun is translated into kaти: Maka jika kamu tidak dapat membuatnya dan pasti kamu tidak akan dapat membuatnya peliharalah dirimu dari neraka yang bahan bakarnya manusia dan batu [Al Baqarah (2): 24].

Indonesian uses the word akan to show future tense, but the pronoun that is used is similar, that is $a k u$. Meanwhile, Arabic differentiates the pronoun in terms of tense.

Al Baqarah (2): 35

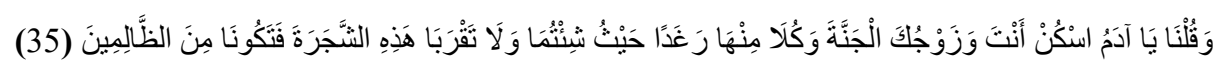

"Dan kami berfirman: Hai Adam diamilah oleh kamu dan istrimu surga ini dan makanlah makanan-makanannya yang banyak lagi baik di mana saja yang kamu suka dan janganlah kamu dekati pohon ini yang menyebabkan kamu termasuk orang yang zalim".

This example shows the difference in Arabic. In Arabic, there is grammatical conformity between the verb and the subject or between the adverb with the number, person, and gender. A perfect verb in Arabic has different inflection based on the different person, number, and gender. It has 14 forms that are changed through suffix inflection (Nur, 2010: 85).

"Kami berfirman: turunlah kamu semua dari sorga itu! Kemudian jika datang petunjukku kepadamu maka barang siapa yang mengikuti petunjukku niscaya tidak ada kekhwatiran atas mereka dan tidak pula mereka bersedih hati"

The Difference of Personal Pronoun In Honorific Perspective

The difference of personal pronoun in honorific perspective should also be a concern, considering the choosing of second personal pronoun for Allah is Engkau while it will be unfitting to refer teacher or parents as engkau. This pronoun is seen as unethical by the students to their teacher or the children to their parents. Even, teachers or parents can get mad if they are to be greeted as engkau. Oddly, the pronoun engkau can be used to refer Allah in some translations in Al Quran, considering the fact that Allah is The Almighty (على); The Creator (خالقى).

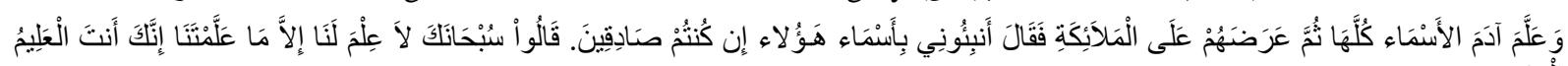


Dan Dia mengajarkan kepada Adam Nama-nama (benda-benda) seluruhnya, kemudian mengemukakannya kepada Para Malaikat lalu berfirman: "Sebutkanlah kepada-Ku nama benda-benda itu jika kamu memang orang-orang yang benar!" Mereka menjawab: "Maha suci Engkau, tidak ada yang Kami ketahui selain dari apa yang telah Engkau ajarkan kepada kami; Sesungguhnya Engkaulah yang Maha mengetahui lagi Maha Bijaksana." [Al-Baqarah (2): 31 32]

In the above quotation, there are third personal pronoun Dia and second personal pronoun Engkau. As stated in KBBI (2007 p 810) there are some words used as honorific reference for the high ones (authorities, noblemen, king), which is paduka. Why does the translation of personal pronoun for Allah not use Paduka as it is more honorific compared to Engkau? The same problem also happens to Dia. In KBBI (2007 p 127) there is another word beliau that can be used to refer to the person (to honor him/her). Beliau is also not used in the translation of Al Quran to refer to Allah. This shows that there were some differences in the use of second and third personal pronoun between Indonesian and Arabic seen through its honorific aspect (personal pronoun honorific).

\subsection{Translation of Honorific Pronouns}

In certain time, personal pronoun is not mentioned in the translation because the translator considers the aesthetic aspect of the language. Take a look QS Ali Imron ((3): 5) below:

Ali Imron (3): 5

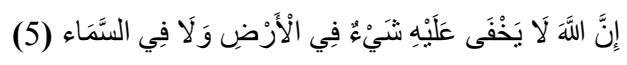

"Sesungguhnya bagi Allah tidak ada satupun yang tersembunyi di bumi dan tidak pula di langit".

The literal translation of this verse is "Sesungguhnya Allah tidak tersembunyi atas-Nya sesuatu pun di bumi ataupun di langit". The personal pronoun -Nya is omitted and the above translation is considered more aesthetic.

The pronoun used for Allah is paduka, not engkau (Tim Redaksi KBBI, 2005:303). Engkau is usually used as the personal pronoun for someone who is in the similar or lower position. However, engkau is usually used as pronoun for the word anta ( (in Arabic or possesive pronoun $k a$ (ك) (ك) even though it is used for Allah.

Translation theory states that "In translating the text, a translator should understand well in both language and cultures; text to be translated; and translation theory (House, 2002:97). Related to the aforementioned theory, the differences in translation from some point of views do not mean that the translator is incapable of mastering both languages (source and target language). The differences are caused by the different system in both languages (Indonesian and Arabic). The system in Indonesian language does not include the difference of personal pronoun based on gender, number, and time. According to Kridalaksana (1986) and Moeliono 1988) pronoun is classified into two: definite and indefinite pronoun. Definite pronoun is used for definite reference that is personal pronoun. It consists of first, second, and third personal pronouns in both plural and singular forms.

This means, the difference happens due to linguistic problems as it is stated by Izzan (2007). The difference in the translation of second and third personal pronoun seen through its honorific aspect can be understood as one of the challenges in translation. This phenomenon is similar to the one stated by Izzan (2007). He stated that the socio-cultural aspect between Indonesia and Arab must be different. This difference caused a challenge in translation. The translator's incapabilities can be one of the factors that cause the un-fixed translation of personal pronoun in the honorific perspective. This means that the translator still lack of understanding until its socio-linguistic aspect, especially on the politeness in using language.

The differences in the translation of personal pronouns especially seen through gender and time aspect between Indonesian and Arabic shows the difference with the researches done by Munifatullah (2010). Munifatulah (2010) concluded that in Minangkabau, social variable (e.g. age, gender, occupation, and education background) and functional variable (relations among speakers, level of formality, genre, topics, and speech plot) influence the use of personal pronoun. The research shows that age and relation among speakers become the most influential factor.

The findings of this research found are different to the research conducted by Prayogi (2012). The research found that there are only three syllables that become the pronoun clitics, those are $k u, m u$, and $n y a$, with $k u-,-m u$, and $-n y a$ as the proclitic. He stated that proclitic is only attached to the verb or other category which has been derived into verb. Meanwhile, enclitic is attached to transitive verb and noun. The change from pronoun into affix can be seen by the various use of -nya, either as clitic, affix, or pen topic particle. He also concluded that $d i$ - becomes passive prefix. The main difference of both researches is Prayogi's (2012) research focused the object on the clitical pronouns, while this research does not only focus on the clitical personal pronouns.

This research is also different if compared to Dehcheshmeh's (2013) findings, that is on the exclusiveness and inclusiveness of first personal pronoun. The research can be concluded that: on the whole, the exclusive and inclusive uses diexis 'ma' indicate the communicative role of authors with their readers in artistic and scientific texts. This research do not discuss on the use and translation process of personal pronoun from diexis aspect, while Dehcheshmeh's (2013) focused on diexis aspect.

The analysis shows that personal pronoun used in the translation of the Quran often has different forms as compared to the Indonesian version. Indonesian does not distinguish the pronoun for male and female, but Arabic does. For example, ardhi' iihi is used to refer to imperative for female, while adhi' $i$ h (shorter) is used to refer to imperative for male. Both Indonesian and Arabic have neutral form, and thus neutral pronoun is translated into neutral in Indonesian. In terms of number, the different form of pronoun is applied among the two languages. Indonesian kami is used more often to refer 
to plural noun. Nevertheless, in certain context, it is also used to refer to singular. Indonesian kamu is used to refer to both singular and plural noun. Dual number is distinguished from the singular and plural by add the word berdua to the word kати (kати berdua). In terms of tense, Indonesian and Arabic utilize different systems. While Indonesian does not distinguish the pronoun in terms of past, present, or future tense, Arabic adjusts the grammatical conformity between the verb and the subject or between the adverb and the subject in relation to number, person, and gender to express an embedded element of time. There were some differences in translating second and third personal pronoun between Indonesian and Arabic if seen from honorific aspect. It was found that personal pronoun is sometimes omitted in the translation of the Quran to retain the aesthetic aspect of the language.

The theories applied in this research are translation, linguistic unit, and pronouns, more specifically their function, category, and role. In translating, a text in source language is replaced by a functionally equivalent text in target language (House, 2002). In translating the text, a translator should understand well in both language and cultures; text to be translated; and translation theory. McGuire (1991) said that "translator should have a perfect knowledge of both source language and target language." According to Razmjou (2004) "a good translator is someone who has a comprehensive knowledge of both source and target languages" that is supportedbyBrislin (1976) "Translator should know both the source and receptor languages, should be familiar with the subject matter, and should have facility of expression in the receptor language." Besides, Leonardi (2000) stated that "In fact, when a message is transferred from the SL to TL, the translator is also dealing with two different cultures at the same time". In translating a text, the translator does not only deal with both texts but also all linguistic units, such as words, phrases, clauses, sentences, and paragraph. She or he should determine equivalent linguistic units precisely in the target language, including pronoun.

Nida explained that translation process usually went through three steps (Farisi, 2011): (1) analysis step as to understand the source text through linguistic and meaning analysis, understanding the material to be translated, and understanding the cultural context, (2) translation process in the source text, (3) reconstruction process as an effort to reconstruct the translated sentences to form the final translation result in target language. Moeliono (1989) believes that translation is an activity of reproducing message in source text into its closest and most common equivalent in target language, either seen through its meanin or style.

A good translation will feel sensible, natural, and do not feel like a translation at all. In the practice, reproducing message in the source language necessitates on some adjustments, either in grammatical, lexical, or cultural. Some adjustments are needed to be done in presenting the closest and most natural equivalent of the words (Farisi, 2011).

Another theory applied in this research was functional grammar, which was developed from Verhaar (1977). The functional grammar is used to analyze the function of a lingual unit of a complete sentence which consists of subject, predicate, object, complement, and adverb (Markhamah, 2011a).

Other research on personal pronoun was conducted in Persian language by Dehcheshmeh, (2013), that is on the exclusiveness and inclusiveness of first personal pronoun. The research can be concluded that: on the whole, the exclusive and inclusive uses diexis ' $m a$ ' indicate the communicative role of authors with their readers in artistic and scientific texts. Considering the monolingual corpus, the findings show that the authors pay more attention to themselves and their team in the both texts, but using neither inclusive nor exclusive 'ma' in artistic texts is concederd as the main difference between artistic and scientific texts. This indicates that authors have more power to communicate with their readers in scientific texts than in artistic texts. The findings of the study have main implication for linguistics. Linguistics students can recognize the ability of authors to communicate with their readers. In future investigations, inclusive and exclusive uses of Persian first plural can be studied in sientific and political texts. This information can help authors to use more inclusive and exclusive 'ma' in their texts to attract more readers. Moreover, the principal choice of the authors in using specific diexis can be indicative of their strategy to ascribe roles to themselves and their readers throughout a text.

\section{Conclusion}

Anchored in the analyzed and discussed of the data found, this study concludes that in terms of gender, personal pronoun has different translation in the two languages. Indonesian does not distinguish the personal pronoun that refers to male or female, while Arabic does. In terms of quantity, Indonesian first person pronoun kami 'we' is commonly used for plural. However in the translated verses, kami 'we' refers to both singular and plural. Furthermore, in terms of tenses, Indonesian and Arabic utilize different systems. Indonesian does not distinguish the pronoun in terms of past, present, or future act, while Arabic adjusts the grammatical conformity between the verb and the subject or between the adverb and the subject in relation to number, person, and gender to express an element of tense.

\section{References}

Adifitrah, M.Y. (2014). Learning Arabic for Indonesian.Surakarta: Gazzamedia

Brislin, R. (1976). Translation: Application and Research. New York: Gardner Press Inc.

Dehcheshmeh, SM. (2013). Exclusive and Inclusive Uses of Persian First Person Plural: Sience VS Art. International Journal of Linguistics Available at: http://www.macrothink.org. 5 (2): 135-146. Accessed at 14 January 2016.

Engineer, A.A. (2002). Islam And Poligamy. in Musyawa: Jurnal Studi Gender dan Islam. pp. 27-39.

Faisal, A. (2002). The Concept of Wawwam in Koran (An Approach of Meaning Field Theory). in Relasi Jender dalam Islam Surakarta: Pusat Studi Wanita STAIN Surakarta. pp. 34-46. 
Izzan, A. (2007). Arabic Learning Methodology. Bandung: Humaniora

Hatta, A. (2009). Koran Intrepretasion by Words. Jakarta: Pustaka Maghfirah.

House, J. (2002). Universality Versus Culture Specificity in A Riccardi Translation Studies: Perspectives on an Emerging Discipline. Cambridge: Cambridge University Press.

Koban, D. (2011). Continuity of Reference and Subject Personal Prounoun Variation in the Turkish Spoken in Turkey and in New York City. Australian Journal of Linguistics, 31 (3), 351-369

Kridalaksana, H. (1986). Part of Speech in Indonesian: PT Gramedia.

Kridalaksana, H. (1993). Linguistic Dictionary. Jakarta: PT Gramedia Pustaka Utama.

Kummerow, D. (2012). 'The Person That Isn't: On Defining the Third-Person, Negatively and Positively So'. Australian Journal of Linguistics, 32(2): 259-290.

eonardi, V. (2000). 'Equivalence in Translation: Between Myth and Reality'. Accurapid Translation Journal. 4 (4) Available at http://accurapid.com/journal/. Accessed at 8 January 2016

Manns, H. (2012). 'First-Person Pronominal Variation, Stance, and Identity in Indonesia' Australian Journal of Linguistics 32 (4): 435-456

Markhamah. (2002). Morality of Koran: The Deterrent for Nation's Disintegration in Sumiyati As. (Ed.). Integration, Nation's Morality and Change Yogyakarta: Fakultas Ilmu Budaya, UGM.

Markhamah. (2003a). Gender in Translated Koran on Male and Female. Profetika pp. 23-35.

Markhamah. (2003b) Gender Equality in Koran. Seminar Nasional Hasil Penelitian, Balitbang Jateng

Markhamah. (2007). 'The Development of Speech Participant Concept on Religion Texts'. Research Report Fundamental Tahun I Surakarta: Universitas Muhammadiyah Surakarta.

Markhamah. (2008). 'The Development of Speech Participant Concept on Religion Texts' Research Report Fundamental Tahun II Surakarta: Universitas Muhammadiyah Surakarta.

Markhamah, A Sabardila, Sangidu, AH Prabawa \& Hindun. (2008a). The Compendium of Kompendium Himpunan Ayat-ayat Quran tentang Etika Berbahasa. Surakarta: Muhammadiyah University Press.

Markhamah, A. Sabardila, Sangidu, A. H. Prabawa, Hindun. (2008b). Compendium of Hadith on Language Ethics: A Sociolinguistic Perspective. Surakarta: Muhammadiyah University Press.

Markhamah \& A. Sabardila. (2009). Analisis Kesalahan dan Kesantunan Berbahasa. Surakarta: Muhammadiyah University Press.

Markhamah. (2009a). 'Speech Participant in Translated Koran'. In D Purnanto, K Saddono \& HJ Prayitno (Eds.). Panorama Pengkajian Bahasa, Sastra, dan Pengajarannya. Surakarta: Penerbit Program S3 dan S2 Pascasarjana dan Fakultas Sastra dan Seni Rupa. Universitas Sebelas Maret.

Markhamah \& A. Sabardila. (2010). Syntax 2: The Harmony of Functions, Categories and Roles on Clauses. Surakarta: Muhammadiyah University Press.

Markhamah, A Ngalim \& MM Basri. (2011). 'Teaching Material Development and Syntax Learning Based on Translated Koran' Research Report Hibah Tim Pascasarjana Surakarta: Universitas Muhammadiyah Surakarta

Markhamah. (2011). Ragam Variety and Analysis of Sentence in Indonesian. Surakarta: Muhammadiyah University Press.

Markhamah, A. Ngalim \& MM Basri. (2012). Teaching Material Development and Syntax Learning Based on Translated Koran. Research Report Hibah Tim Pascasarjana Surakarta: Universitas Muhammadiyah Surakarta

Markhamah, A. Ngali, MM Basri \& Susilowati. (2012). Substitution Transformation on Translated Koran Which Contains Language Ethics. Paper at Diskusi Program Magister Pengkajian Bahasa, Pascasarjana, Universitas Muhammadiyah Surakarta, 15 Agustus 2012.

Markhamah, A. Ngalim, MM Basri, A Sabardila \& Shofiyuddin. (2013). Appendix in Translated Koran. Seminar Internasional PIBSI. pp. 30-31

Markhamah \& A. Sabardila. (2013). Language Politeness: Translated Koran and Hadith's Perspective. Seminar Nasional Kesantunan Berbahasa dalam Berbagai Perspektif Universitas Muhamamdiyah Surakarta. pp. 258-288

Maslamah. (2002). 'Feminism in Koran’ Relasi Gender Dalam Islam Surakarta: Pusat Studi Wanita STAIN Surakarta Press. pp. 67-78

McGuire, S. B. (1991). Translation Studies. London and New York: Routledge.

Moeliono, A. M. (1988). Indonesian Standard Grammar. Jakarta: Perum Balai Pustaka.

Munifatullah, F. (2010). Pronoun on Standard Minang: A Sociolinguistic Study’ Tesis. Yogyakarta: Universitas Gadjah Mada.

Pamungkas, P. (2013). Self-taught Arabic Jakarta. Pustaka Makmur

Nurhayati. (2009). Speaker's Strategy in Choosing the form of Personal Pronoun, Collective Noun and Proper Noun in Teenage Movies. Linguistik Indonesia: Jurnal Ilmiah Masyarakat Linguistik Indonesia, 27 (1), 97-112. 
Nur, T. (2010). The Function of Inflectional Affixes as Person, Number and Gender in Arabic Verbs from Inflectional and Derivational Morphological Perspective. Humaniora, Jurnal budaya, Sastra, dan Bahasa, 22 (1), 75-85.

Prayogi, I. (2012). Clitic Pronoun in Bahasa Indonesia Tesis. Yogyakarta: Universitas Gadjah Mada.

Rahman, Y. (2012).Deixis in German.Tesis. Yogyakarta: Universitas Gadjah Mada.

Rachmawati, R.A. (2013). The Grammatical Forms of Personal Pronoun in Bahasa Indonesia: A Structuralism Study. Available at http://dglib.uns.ac.id/pengguna.php?mn=detail\&d_id=1073.

Rohmadi, M., Nasucha, Y., \& A.B. Wahyudi. (2012). Morphology: Study of Morpheme and Word. Surakarta: Yuma Pustaka.

Razmjou, L. (2004). 'To be a Good Translator Accurapid. Translation Journal, 8(2), Available at http://accurapid.com/journal/ Accessed at 12 January 2016

Sabardila, A., Sangidu, A. H. Prabawa \& Hindun. (2003). Language Ethics in Koran' Research Report. Surakarta: Universitas Muhammadiyah Surakarta.

Sabardila, A., Sangidu, A. H. Prabawa \& Hindun. (2004). Language Ethics in Hadith. Research Report. Surakarta: Universitas Muhammadiyah Surakarta.

Setiawan, T. (2012). Indonesian Definite Nominals in Elementary School Students' Writing.Disertasi. Program Studi Pendidikan Bahasa Indonesia, Program Pascasarjana, Universitas Negeri Malang.

Sulistyowati, H. (2012). Attributive Structure in Indonesian Phrase Disertasi. Available at http://karyailmiah.um.ac.id/index.php/disertasi/article/view/8757 Accessed at 14 January 2016.

Alwi, H (ed.). (2007). Indonesian Dictionary (3 th. Ed.). Jakarta: Balai Pustaka.

Umar, N. (2001). Gender Equality Arguments in Koran's Perspective. Jakarta: Paramida

Verhaar, J. W. M. (1977). Introduction to Linguistics: First Edition. Yogyakarta: Gadjah ada University Press.

Zaid, M. A. (2011). "Language Acquisition, Linguistic Creativity and Achievement: Insights from the Quran. Kemanusiaan: The Asian Journal of Humanities 18 (2), 75-10 